\title{
Continual Quality Improvement of Online Course Delivery Using Perceived Course Learning Outcomes
}

\author{
Thirumeni T Subramaniam* and Nur Amalina Diyana Suhaimi \\ Centre for Research and Innovation, Open University Malaysia, Kuala Lumpur, Malaysia \\ *thirumeni@oum.edu.my
}

Published online: 29 July 2019

To cite this article: Subramaniam, T. T. and Nur Amalina Diyana Suhaimi. 2019. Continual quality improvement of online course delivery using perceived course learning outcomes. Malaysian Journal of Distance Education 21(1): 43-55. https://doi.org/10.21315/ mjde2019.21.1.3

To link to this article: https://doi.org/10.21315/mjde2019.21.1.3

\begin{abstract}
The objective of an education programme is to enable its learners to successfully achieve the programme outcomes. Programme outcomes can be effectively mapped into the courses within a programme. The achievement of the course learning outcomes can therefore be used to indicate the achievement of the programme outcomes. In an effort to ensure the continuous quality improvement of the education services offered, the Open University Malaysia uses a survey instrument to capture the perception of learners on the contributions of the various parts of online course delivery in their achievement of the expected learning outcomes. Such learners' perceptions are seen important in sustaining their motivation and persistence in completing their studies. There are 19 items measured using 5-point Likert scales and one open-ended response. The items cover the online course delivery parts including course module, workload, resources, learning tasks, online forum interactions, assessments, learning platform, overall online course organisation and the learning experience. Additional items measuring the learners' motivation, attitude, engagement and satisfaction were also included. The targeted population in this study are all the learners in 40 fully online courses offered in January 2017 semester. The findings help the university to identify the perceived effectiveness of the aspects of the online course delivery and the correlations between the items to the learners' motivation, attitude, engagement and satisfaction. Multiple regressions were also used to analyse the relationships. The output is an online course evaluation system that facilitates continual quality improvement efforts.
\end{abstract}

Keywords: online course delivery, learning outcomes, evaluation, continuous quality improvement

(C) Penerbit Universiti Sains Malaysia, 2019. This work is licensed under the terms of the Creative Commons Attribution (CC BY) (http://creativecommons.org/licenses/by/4.0/). 


\section{Introduction}

Open and distance education sector is a rapidly evolving service sector in a world that is much dominated by technology and media. Private open and distance learning (ODL) provider such as the Open University Malaysia (OUM) must take initiatives to be in the frontiers of online programme delivery. At OUM, the delivery of programmes through blended-learning mode or online-learning mode is designed based on the guidelines provided by the Malaysian Qualifications Agency. Blended learning is a popular choice among ODL institutions as a strategy to support its students who are mostly working adults who have left the education system for a significant period of time. As the demography of the students at OUM change over time towards students who are much more familiar with information communication technology or ICT, the shift towards a learning environment that is fully supported by an online system is seen as an ideal choice to facilitate working adult learners. Dobbs, Waid and del Carmen (2009) pointed out the positive comments regarding online learning which offers greater flexibility (and convenience). A study by Leonard and Guha (2001) (as cited by Dobbs, Waid and del Carmen, 2009) showed that online environment could provide a better learning environment despite the challenges it poses when compared to traditional courses. Innovations in ICT as well as in Instructional Design have led to the design of e-learning platforms that can present a learning environment with enhanced opportunities for student engagement, interaction and learning (Ituma, 2011). Studies have shown that students' online experience can be academically challenging, and offer better learning opportunities and greater peer-peer interactions (Dobbs, Waid and del Carmen, 2009; Wyatt, 2005).

The input from learners (the key stakeholder and the client) in the education sector is highly important and is a requirement in Total Quality Management or Continuous Quality Improvement (CQI). This is supported by Eom, Ashill and Wen (2006) who highlighted the use of perceived learning outcomes and satisfaction as the goals of educational outcomes in a distance delivery system that uses computer-based instructional systems. The ultimate aim of a good curriculum delivery has two aspects: (i) efficiency-measured by ensuring that the targeted learning outcomes are achieved through learning strategies that supports diverse group of learners, and (ii) effectivenessmeasured through a well-designed assessment that measures the targeted 
learning outcomes. This study intends to provide additional perspective on the measured effectiveness.

Adult learners who are assumed to be self-directed learners and thus are responsible for their learning are the best judge over the impact of the delivery modes to their achievement of the learning outcomes.

This study aims to:

(i) determine whether or not the workload for each course is perceived as appropriate by the students [the term workload refers to the number of hours that a student is expected to work on achieving the learning outcomes of a course (Kember, 2004)];

(ii) determine how well the various aspects of the students learning experience are perceived effective by the students in supporting their efforts in achieving the course learning outcomes; and

(iii) determine the students'level of motivation, self-initiatives, engagement and satisfaction associated with course.

The research questions that are addressed in this study are:

(i) how well do the students perceive that the course workload covered in the course appropriate for the achievement of the identified course learning outcomes?

(ii) how well do the students perceive that the various aspects of their online learning experiences support their effort in achieving of the identified course learning outcomes?

(iii) what are the students' level of motivation, self-initiatives, engagement and satisfaction associated with course?

\section{Literature Review}

Course evaluation by learners is not uncommon. Much of the course evaluation carried out using the perspectives of learners were focused on teaching effectiveness (Tucker, Halloran and Price, 2013). The lack of research on perspectives of learners on teaching and learning in the online environment was highlighted by Gilbert (2007, as cited by Tucker, Halloran and Price, 2013). The use of perceived learning outcomes for COI using 
self-administered surveys have been explored by several researchers (Eom, Ashill and Wen, 2006; Dobbs, Waid and del Carmen, 2009; Tucker, Halloran and Price, 2013). In addition, the adoption online environment with the tendency to model the constructivist approach which promotes reflective and deep learning, as highlighted by Ituma (2011), further validates the use of perceived learning outcome as CQI.

According to Paechter, Maier and Macher (2010), a learning environment that relies on online interaction that enable students to process and construct knowledge may refer to the following five segments: i) course design, learning materials and electronic course environment; ii) interaction between students and an instructor; iii) interaction with peer students; iv) individual learning processes; and v) course outcomes. Course outcomes may refer to cognitive or emotional variables. The dimensions identified by Paechter et al. were used to form the framework that was used to adapt the questionnaire from Curtin University (refer work by Tucker, Halloran and Price, 2013). The questionnaire was also adapted to suit the institution's course delivery environment (with permission from the author). Perceived learning outcome achievements in this study refer to both cognitive and emotional variables, within which satisfaction with a course is an important emotional variable. Satisfaction with a course influences the decision to continue or drop-out a course (Chiu, Hsu, Sun Lin and Sun, 2005; Levy, 2007; as cited by Paechter, Maier and Macher, 2010).

\section{Methodology}

This study is based on quantitative research design using an adapted questionnaire (Tucker, Halloran and Price, 2013).

\section{Sample and Procedure}

The population for this study consist of all learners from 40 fully online courses offered in January 2017 semester. Targeted respondent $(N=5974)$ were given the link to submit their responses to the online survey that is hosted in myINSPIRE, the learning platform at OUM. They were encouraged to reflect on their teaching and learning experiences and their contributions to learning. The online survey is conducted for one month from March to 
April 2017. The response rate is $8.8 \%$. The completed useable responses are only 520 across the 40 fully online courses. The data were analysed using SPSS Software version 22.

\section{Measures}

The instrument used in this study consists of 19 items measured using 5 pointLikert scales: 1 (Strongly Disagree), 2 (Disagree), 3 (Neutral), 4 (Agree), and 5 (Strongly Agree); and one open-ended question. The data obtained from respondents were: course learning outcome in course module, course workload covered in the course, learning resources provided, learning task, peer interaction in the online forum, formative and summative assessment, features in myINSPIRE, online course organisation, learning experiences, learners' motivation, attitude in achieving the learning outcomes and learners' satisfaction with their course. One open-ended item was included in the survey to identify ways that can enrich learners' learning experience when taking fully online course.

\section{Method of Analysis}

Data analysis such as reliability test, descriptive statistics, and multiple regression analysis were carried out. This study is focused on: i) learners' motivation, ii) learners' learning experience iii) attitude, iv) overall organisation of the online courses and, v) learners' satisfaction.

\section{Research Findings and Discussion}

The findings in this study are deliberated in the following sub-sections.

\section{Perceived Workload and Learning Outcomes}

The means and standard deviations in Table 1 show that the respondents who are OUM online learners find that in general the course learning outcomes are clearly identified in the course modules (3.75). The findings also show that in general the workload of the course undertaken is seen appropriate (with an overall mean 3.71). The modules were generally found to be useful in helping learners achieve their learning outcomes. 
The summative assessments were perceived to measure the learning outcomes of the course. OUM's e-learning platform, myINSPIRE is seen to have user friendly features that support learners in achieving their learning outcomes.

The learners also indicated that they are motivated to achieve the targeted course learning outcomes; have a positive attitude and are more engaged in achieving the course learning outcomes.

While the range between the means is not large (0.26) with an average mean of 3.65 , there are three items that have been shown to have relatively low mean values (see items in bold in Table 1): i) interaction with peers (3.50), ii) complementary materials (3.51), and iii) overall organisation of the course (3.53).

Table 1 The overall means and standard deviations (40 fully online courses)

\begin{tabular}{lcc}
\hline Items & Mean & Std. Dev \\
\hline $\begin{array}{l}\text { 1. The course learning outcomes are clearly identified in the } \\
\text { course modules. }\end{array}$ & 3.75 & 0.772 \\
2. The course workload covered in this course is appropriate. & 3.71 & 0.757 \\
3. The content of the course module helps me to achieve the & 3.71 & 0.773 \\
$\quad \begin{array}{l}\text { learning outcomes. } \\
\text { The learning instructions incorporated in the course module }\end{array}$ & 3.67 & 0.782 \\
$\begin{array}{l}\text { helps me to achieve the learning outcomes. } \\
\text { The learning resources provided for this course got me }\end{array}$ & 3.63 & 0.791 \\
$\begin{array}{l}\text { engaged in the learning process. } \\
\text { There are sufficient tasks to develop practical skills required } \\
\text { in the course. }\end{array}$ & 3.59 & 0.799 \\
$\begin{array}{l}\text { 7. myINSPIRE, OUM's e-learning platform has user friendly } \\
\text { features that supports me in achieving the learning }\end{array}$ & 3.74 & 0.875 \\
$\begin{array}{l}\text { outcomes. } \\
\text { The overall organisation of the online course makes it easy } \\
\text { for me to go through the learning process. }\end{array}$ & 3.53 & 0.953 \\
$\begin{array}{l}\text { 9. My learning experiences in this course help me to achieve } \\
\text { the learning outcomes. }\end{array}$ & 3.67 & 0.780 \\
$\begin{array}{l}\text { 10. Complementary materials provided for the course help me } \\
\text { to achieve the learning outcomes. }\end{array}$ & 3.51 & 0.916 \\
\hline
\end{tabular}


Table 1 (Continued)

\begin{tabular}{|c|c|c|}
\hline Items & Mean & Std. Dev \\
\hline $\begin{array}{l}\text { 11. The quality of teaching/facilitation/interaction by the course } \\
\text { e-tutor in the online forum helps me to achieve the learning } \\
\text { outcomes. }\end{array}$ & 3.60 & 0.954 \\
\hline $\begin{array}{l}\text { 12. My interaction with peers in the online forum helps me to } \\
\text { achieve the learning outcomes. }\end{array}$ & 3.50 & 0.910 \\
\hline $\begin{array}{l}\text { 13. The formative assessment tasks (self tests, etc) evaluate my } \\
\text { achievement of the learning outcomes. }\end{array}$ & 3.60 & 0.810 \\
\hline $\begin{array}{l}\text { 14. The assignment feedback provided by the e-grader helps me } \\
\text { to achieve the learning outcomes. }\end{array}$ & 3.60 & 0.834 \\
\hline $\begin{array}{l}\text { 15. The summative assessment (final examination) in this } \\
\text { course evaluates my achievement of the learning outcomes. }\end{array}$ & 3.68 & 0.765 \\
\hline $\begin{array}{l}\text { 16. I am motivated to achieve the learning outcomes in this } \\
\text { course. }\end{array}$ & 3.74 & 0.791 \\
\hline $\begin{array}{l}\text { 17. I plan to make the best use of the learning experiences } \\
\text { provided in this course. }\end{array}$ & 3.69 & 0.803 \\
\hline $\begin{array}{l}\text { 18. I often think about how I can achieve my learning outcomes } \\
\text { and learn more effectively in this course. }\end{array}$ & 3.76 & 0.787 \\
\hline $\begin{array}{l}\text { 19. I am satisfied with my achievement of the learning } \\
\text { outcomes in this course. }\end{array}$ & 3.61 & 0.830 \\
\hline
\end{tabular}

The general view presented above is tested by comparing the perception of the respondents between two courses which happen to have larger student numbers. The instrument is designed to evaluate individual online courses. The items (other than item 7 and 8 in the tables) are naturally different and therefore should be analysed by the courses. Nevertheless, many courses have few learners (less than 30) and thus were not analysed in this paper. The analysis in Table 1 was done to identify salient areas that would need to be addressed. The analysis presented in Table 2 depict the data for two online courses that was selected to clearly depict the evaluation of the online courses with different scenarios, Marketing Management I (MM), with $N=40$; and Principles of Macroeconomics (PM), with $N=50$.

\section{Perceived Workload and Learning Outcomes for Selected Courses}

Respondents from MM and PM courses are generally satisfied with their course learning outcomes achievement (mean values above 3 ), and the mean 
values for the respective course (3.78 and 3.46) are significantly different. The independent $t$-test presented in Table 2 shows that the responses for 9 of 19 items tested are significantly different. In answering the first research question, the overall mean had indicated that the learners found the course workload is appropriate. While this was found to be highly agreeable for the MM course, the PM students were less agreeable. This proves that it is possible to evaluate the quality of the courses delivered using this measure. Nevertheless, there is a need to carry out further tests to evaluate the items used and to improve the instrument used.

Table 2 Independent $t$-test: A comparison between the responses from MM and PM Learners

\begin{tabular}{|c|c|c|c|c|c|c|c|}
\hline \multicolumn{2}{|c|}{ Items } & \multirow{2}{*}{$\begin{array}{c}\text { Mean } \\
(\mathrm{MM}) \\
3.90\end{array}$} & \multirow{2}{*}{$\begin{array}{c}\text { Mean } \\
(\mathrm{PM})\end{array}$} & \multirow{2}{*}{$\begin{array}{c}\text { F } \\
(\text { Sig. }) \\
0.602 \\
(0.44)\end{array}$} & \multirow{2}{*}{$\begin{array}{c}\begin{array}{c}t \\
(p \text {-value })\end{array} \\
2.128 \\
(0.036)\end{array}$} & \multirow{2}{*}{$\begin{array}{c}\text { Mean } \\
\text { Diff } \\
0.34\end{array}$} & \multirow{2}{*}{$\begin{array}{c}\text { Remark } \\
\text { SIG }\end{array}$} \\
\hline 1. & $\begin{array}{l}\text { The course learning } \\
\text { outcomes are clearly } \\
\text { identified in the course } \\
\text { modules. }\end{array}$ & & & & & & \\
\hline 2. & $\begin{array}{l}\text { The course workload } \\
\text { covered in this course is } \\
\text { appropriate. }\end{array}$ & 3.80 & 3.62 & $\begin{array}{l}2.055 \\
(0.15)\end{array}$ & $\begin{array}{c}1.171 \\
(0.245)\end{array}$ & 0.18 & $\begin{array}{c}\text { NOT } \\
\text { SIG }\end{array}$ \\
\hline 3. & $\begin{array}{l}\text { The content of the } \\
\text { course module helps me } \\
\text { to achieve the learning } \\
\text { outcomes. }\end{array}$ & 3.85 & 3.54 & $\begin{array}{c}1.799 \\
(0.183)\end{array}$ & $\begin{array}{l}1.989 \\
(0.05)\end{array}$ & 0.31 & SIG \\
\hline 4. & $\begin{array}{l}\text { The learning instructions } \\
\text { incorporated in the } \\
\text { course module helps me } \\
\text { to achieve the learning } \\
\text { outcomes. }\end{array}$ & 3.88 & 3.52 & $\begin{array}{c}1.636 \\
(0.204)\end{array}$ & $\begin{array}{l}2.201 \\
(0.03)\end{array}$ & 0.36 & $\mathrm{SIG}$ \\
\hline 5. & $\begin{array}{l}\text { The learning resources } \\
\text { provided for this course } \\
\text { got me engaged in the } \\
\text { learning process. }\end{array}$ & 3.73 & 3.52 & $\begin{array}{c}1.409 \\
(0.238)\end{array}$ & $\begin{array}{c}1.276 \\
(0.205)\end{array}$ & 0.21 & $\begin{array}{l}\text { NOT } \\
\text { SIG }\end{array}$ \\
\hline 6. & $\begin{array}{l}\text { There are sufficient tasks } \\
\text { to develop practical skills } \\
\text { required in the course. }\end{array}$ & 3.78 & 3.40 & $\begin{array}{c}3.059 \\
(0.084)\end{array}$ & $\begin{array}{l}2.370 \\
(0.02)\end{array}$ & 0.38 & SIG \\
\hline
\end{tabular}


Table 2 (Continued)

\begin{tabular}{|c|c|c|c|c|c|c|c|}
\hline \multicolumn{2}{|c|}{ Items } & \multirow{2}{*}{$\begin{array}{c}\text { Mean } \\
(\mathrm{MM})\end{array}$} & \multirow{2}{*}{$\begin{array}{r}\begin{array}{r}\text { Mean } \\
(\mathrm{PM})\end{array} \\
3.68\end{array}$} & \multirow{2}{*}{$\begin{array}{c}\text { F } \\
(\text { Sig. }) \\
0.586 \\
(0.446)\end{array}$} & \multirow{2}{*}{$\begin{array}{c}\begin{array}{c}t \\
(p \text {-value })\end{array} \\
\begin{array}{c}0.526 \\
(0.60)\end{array}\end{array}$} & \multirow{2}{*}{$\begin{array}{l}\text { Mean } \\
\text { Diff } \\
0.10\end{array}$} & \multirow{2}{*}{$\begin{array}{c}\text { Remark } \\
\text { NOT } \\
\text { SIG }\end{array}$} \\
\hline 7. & $\begin{array}{l}\text { myINSPIRE, OUM's } \\
\text { e-learning platform has } \\
\text { user friendly features that } \\
\text { supports me in achieving } \\
\text { the learning outcomes. }\end{array}$ & & & & & & \\
\hline 8. & $\begin{array}{l}\text { The overall organization } \\
\text { of the online course } \\
\text { makes it easy for me to } \\
\text { go through the learning } \\
\text { process. }\end{array}$ & 3.63 & 3.42 & $\begin{array}{c}0.218 \\
(0.642)\end{array}$ & $\begin{array}{c}1.057 \\
(0.293)\end{array}$ & 0.21 & $\begin{array}{l}\text { NOT } \\
\text { SIG }\end{array}$ \\
\hline 9. & $\begin{array}{l}\text { My learning experiences } \\
\text { in this course help me } \\
\text { to achieve the learning } \\
\text { outcomes. }\end{array}$ & 3.93 & 3.54 & $\begin{array}{c}4.588 \\
(0.035)\end{array}$ & $\begin{array}{c}2.422 \\
(0.017)\end{array}$ & 0.39 & SIG \\
\hline 10. & $\begin{array}{l}\text { Complementary materials } \\
\text { provided for the course } \\
\text { help me to achieve the } \\
\text { learning outcomes. }\end{array}$ & 3.63 & 3.36 & $\begin{array}{c}0.018 \\
(0.893)\end{array}$ & $\begin{array}{c}1.303 \\
(0.196)\end{array}$ & 0.27 & $\begin{array}{c}\text { NOT } \\
\text { SIG }\end{array}$ \\
\hline 11. & $\begin{array}{l}\text { The quality of teaching/ } \\
\text { facilitation/ interaction } \\
\text { by the course e-tutor } \\
\text { in the online forum } \\
\text { helps me to achieve the } \\
\text { learning outcomes. }\end{array}$ & 3.70 & 3.50 & $\begin{array}{c}0.021 \\
(0.886)\end{array}$ & $\begin{array}{c}1.009 \\
(0.316)\end{array}$ & 0.20 & $\begin{array}{c}\text { NOT } \\
\text { SIG }\end{array}$ \\
\hline 12. & $\begin{array}{l}\text { My interaction with peers } \\
\text { in the online forum helps } \\
\text { me to achieve the learning } \\
\text { outcomes. }\end{array}$ & 3.73 & 3.34 & $\begin{array}{c}4.709 \\
(0.033)\end{array}$ & $\begin{array}{c}2.123 \\
(0.037)\end{array}$ & 0.39 & SIG \\
\hline 13. & $\begin{array}{l}\text { The formative assessment } \\
\text { tasks (self tests, etc) } \\
\text { evaluate my achievement } \\
\text { of the learning outcomes. }\end{array}$ & 3.70 & 3.54 & $\begin{array}{c}0.024 \\
(0.878)\end{array}$ & $\begin{array}{c}0.993 \\
(0.324)\end{array}$ & 0.16 & $\begin{array}{c}\text { NOT } \\
\text { SIG }\end{array}$ \\
\hline 14. & $\begin{array}{l}\text { The assignment feedback } \\
\text { provided by the e-grader } \\
\text { helps me to achieve the } \\
\text { learning outcomes. }\end{array}$ & 3.80 & 3.36 & $\begin{array}{c}0.334 \\
(0.565)\end{array}$ & $\begin{array}{c}2.557 \\
(0.012)\end{array}$ & 0.44 & SIG \\
\hline
\end{tabular}


Table 2 (Continued)

\begin{tabular}{|c|c|c|c|c|c|c|}
\hline Items & $\begin{array}{l}\text { Mean } \\
(\mathrm{MM})\end{array}$ & $\begin{array}{l}\text { Mean } \\
(\mathrm{PM})\end{array}$ & $\begin{array}{c}\mathrm{F} \\
\text { (Sig.) }\end{array}$ & $\begin{array}{c}t \\
\text { (p-value) }\end{array}$ & $\begin{array}{c}\text { Mean } \\
\text { Diff }\end{array}$ & Remark \\
\hline $\begin{array}{l}\text { 15. The summative } \\
\text { assessment (final } \\
\text { examination) in this } \\
\text { course evaluates my } \\
\text { achievement of the } \\
\text { learning outcomes. }\end{array}$ & 3.83 & 3.64 & $\begin{array}{c}0.244 \\
(0.623)\end{array}$ & $\begin{array}{l}1.216 \\
(0.227)\end{array}$ & 0.19 & $\begin{array}{l}\text { NOT } \\
\text { SIG }\end{array}$ \\
\hline $\begin{array}{l}\text { 16. I am motivated to achieve } \\
\text { the learning outcomes in } \\
\text { this course. }\end{array}$ & 3.85 & 3.68 & $\begin{array}{c}1.488 \\
(0.226)\end{array}$ & $\begin{array}{c}0.987 \\
(0.326)\end{array}$ & 0.17 & $\begin{array}{l}\text { NOT } \\
\text { SIG }\end{array}$ \\
\hline $\begin{array}{l}\text { 17. I plan to make the best } \\
\text { use of the learning } \\
\text { experiences provided } \\
\text { in this course. }\end{array}$ & 3.88 & 3.50 & $\begin{array}{c}2.051 \\
(0.156)\end{array}$ & $\begin{array}{l}2.372 \\
(0.02)\end{array}$ & 0.38 & SIG \\
\hline $\begin{array}{l}\text { 18. I often think about how I } \\
\text { can achieve my learning } \\
\text { outcomes and learn more } \\
\text { effectively in this course. }\end{array}$ & 3.98 & 3.56 & $\begin{array}{c}8.983 \\
(0.004)\end{array}$ & $\begin{array}{c}2.853 \\
(0.005)\end{array}$ & 0.42 & SIG \\
\hline $\begin{array}{l}\text { 19. I am satisfied with my } \\
\text { achievement of the } \\
\text { learning outcomes in } \\
\text { this course. }\end{array}$ & 3.78 & 3.46 & $\begin{array}{c}0.283 \\
(0.596)\end{array}$ & $\begin{array}{l}1.906 \\
(0.06)\end{array}$ & 0.32 & $\begin{array}{l}\text { NOT } \\
\text { SIG }\end{array}$ \\
\hline Overall Mean Values & 3.78 & 3.46 & & & & \\
\hline
\end{tabular}

In determining how well the various aspects of learning experience are perceived effective in supporting the learning effort to achieve the targeted learning outcome (the second research question), two items have shown to have low ratings (overall as well as for both MM and PM courses): item 10 and item 12. Item 12 also indicated significantly difference between courses. The rating for item 12 (interaction with peers) by the PM learners is low, 3.34 and the rating given by the MM learners is also low, 3.73. The findings related to the peer interaction for two other courses, Entrepreneurship $(N=112)$ and Professional Ethics $(N=71)$ also showed low ratings (both at 3.54). Such low rating pattern was not observed among other items across the analysed courses. A new study to review the collaboration among peers is being initiated using a selected course as a case study. 
Analysis of items with low mean values among the four courses indicated that there are new items that were rated low for a particular course. The identified items with low ratings for a course must be studied further as part of the CQI process which requires further actions towards improvement and quality assurance. For the entrepreneurship course where the development of practical skills is crucial showed low rating (3.40) for item 6 in Table 2. The ratings of this specific item for the three other courses are not among the lower values. The demand/expectations from the learners may be different and this would influence the findings.

The evaluation of the learning outcomes via the formative assessment tasks for MM was found to have relatively low rating (3.70). This is critical as the formative assessment plays a crucial role in supporting ODL. Similarly, the assignment feedbacks provided by the e-grader which ought to help the learners to achieve their learning outcomes were rated low for PM (3.36). These are concerns that must be explored and improved.

The use of the online course evaluation as CQI enables a key item such as the clear identification of the course learning outcomes to be monitored. This item was generally rated high in most cases. However, this is not true for PM. The rating at 3.56 has a clear gap (0.12) from the high rating given for this course (3.68). This raises a great concern. If the learners are not clear of the learning outcomes they ought to achieve, the course cannot be successfully delivered.

Learners for both courses perceive themselves as motivated, have a positive attitude towards learning and engaged in the learning process. This finding is emphasised by the significant difference between MM and PM learners for items 17 and 18. Nevertheless these perceptions must be tested again. At present, the study is extended to include the perception of course e-tutor(s) to confirm these observations.

\section{Correlation between Perceived Learning Outcomes for Selected Courses}

The linearity of the relationship between the satisfactions in achieving the targeted learning outcomes and the contributions of the various items studied shows a positive correlation with $p=0.000$ for all items. The range of $r$ values (above 0.6), using the guide by Evans (1996), suggests that 
the correlation is strong. Further analysis using linear regression, shows $r^{2}=0.789$ which indicates that about $79 \%$ of the items influences the learner's satisfaction in achieving the learning outcomes. The ANOVA table show the model is significant with $F=108.657$ at $p<0.05$.

However, few items show significant relationship with satisfaction. The only item that shows a clear relationship is the item on the overall organisation of the online course $(B=0.283, p<0.05)$. The implication of this finding is that in monitoring the quality of the online course delivery, the ratings for the item 8 could serve as a good indicator. The overall mean of this rating could be used to alarm the administrators when action is required.

\section{Perceived Learning Outcomes: Open-ended Responses}

The open-ended responses provide a different perspective of learners' views. The number of respondents is much smaller with 148 responses. Among these, 104 responses gave comments on how their learning experience could be enriched. While the mean for e-tutor (3.60) and learning experience (3.67) are not rated low, a quarter (26) of the open-ended responses focused on the e-tutor, and another quarter (25) requested for the face-to-face interactions. An additional 8 responses suggested improved forum interactions. Thus, in establishing an effective CQI, the item 11 ought to be monitored closely. A study by Wyatt (2005), suggests that learners show no difference in their interaction with online tutors or face-to-face tutors in their study. "The teacher of any classroom, whether it has solid walls or is virtual, has much influence in shaping the learning environment and outcomes and carries the responsibility for creating the conditions that encourage a deep approach to learning which demonstrates a dynamic and interactive community of inquiry" (Garrison, Anderson and Archer, 2000; as cited by O'Hare, 2011). Thus, the quality of teaching/facilitation/interaction by a course tutor (e-tutor or face-to-face tutor) lies in the capacity of the tutor in creating such conditions.

A third quarter (23) also suggested enrichment of the learning material, quizzes, and other learning tasks. A small group even suggested improvement of the learning system. No new learning opportunity was suggested. 


\section{Conclusion}

This study highlights OUM learners' perception on the online course delivery and measure important factors that influence their satisfaction on learning experience. The online course evaluation enables OUM to look into aspects for which improvement are needed especially in the organisation of the online course. Several ways to enrich learners' learning experience can be implemented. Thus, the evaluation system is crucial and must be administered in real-time in order to ensure successful course delivery; and that learners can achieve the programme outcomes effectively.

\section{References}

Dobbs, R. R., C. A. Waid and A. del Carmen. 2009. Student's perceptions of online courses, the effect of online course experience. The Quarterly Review of Distance Education 10(1): 9-26.

Eom, S. B., N. Ashill and H. J. Wen. 2006. The determinants of students' perceived learning outcomes and satisfaction in university online education: an empirical investigation. Decision Sciences Journal of Innovative Education 4(2): 215-235. https://doi.org/10.1111/j.1540-4609.2006.00114.x

Evans, J. D. 1996. Straightforward statistics for the behavioral sciences. Pacific Grove: Brooks/Cole Publishing Company.

Ituma, A. 2011. An evaluation of students' perceptions and engagement with e-learning components in a campus based university. Active Learning in Higher Education 12(1): 57-68. https://doi.org/10.1177/1469787410387722

Kember, D. 2004. Interpreting student workload and the factors which shape students' perceptions of their workload. Studies in Higher Education 29(2): 165-184.

O‘Hare, S. 2011. The role of the tutor in online learning. In Proceedings of Ascilite Hobart: changing demands, changing directions, eds. G. Williams, P. Statham, N. Brown and B. Cleland, 909-918.

Paechter, M., B. Maier and D. Macher. 2010. Students' expectations of, and experiences in e-learning: their relation to learning achievements and course satisfaction. Computers \& Education 54(1): 222-229. https://doi.org/10.1016/j. compedu.2009.08.005

Tucker, B., P. Halloran and C. Price. 2013. Student perceptions of the teaching in online learning: An Australian university case study. In 36th HERDSA Annual International Conference, eds. S. Frielick, N. Buissink-Smith, P. Wyse, J. Billot, J. Hallas and E. Whitehead, 470-484. Auckland, New Zealand: Research and Development in Higher Education: The Place of Learning and Teaching. Retrieved from http://www.herdsa.org.au/?page_id $=3502$

Wyatt, G. 2005. Satisfaction, academic rigor and interaction: perceptions of online instruction. Education 125(3): 460-468. 